\title{
THE CHILD IN A CHILD: CHILD MARRIAGE AND LOST IDENTITY IN SOUTHERN AFRICA*
}

Summary: In most communities in sub-Saharan Africa, the definition of a child is culturally, politically, and socially unspecific and varied. The variance in meanings ascribed to a child is evident in legislative definitions, especially on the issue of child marriage. Child marriage, a human rights violation is a legal or customary union in which one or both spouses are below the age of 18. This practice is prevalent in most communities in sub-Saharan Africa. Arguably, it robs children of the opportunity to enjoy childhood and experience dependence, protection, and care. Rather, it turns them into protectors, nurturers, and providers. Children are shoved with the responsibility of being parents through child marriage. Thus, creating no demarcation between the role and responsibility of an adult and a child. Given that children are ill-prepared for marriage and its concomitant elements such as sex, psychological, emotional and physical maturity to be spouses and possibly parents, this paper argues that the journey to self-discovery and identity is at the intersection of culture, law, and religion. The clash between religious and cultural autonomy is a pervasive problem for national and international laws, one that arises because of claims of immunity from child protection and marriage provisions on the grounds of cultural or religious autonomy. Informed by observation during fieldwork in Southern African countries and literature on cultural relativism, this paper suggests that the clash between cultural autonomy and child marriage prohibition is best addressed through a legal pluralist perspective. This perspective seeks to bridge the gap between customary law, national laws, and international treaties, and requires sensitivity to the economic and socio-cultural factors behind the persistence of child marriage.

Keywords: Identity, self-discovery, child marriage, human rights, marriage age

* Jane Diala, LLM, BL, LLB; PhD Candidate at University of Cape Town, Research Assistant at the Centre for Law and Society, University of Cape Town, Private Bag X3, Rondebosch, 7701 South Africa. Email address: jane.diala@alumni.uct.ac.za. ORCID: https://orcid.org/0000-0002-1413-0725

** This article is inspired by the Centre for Law and Society's (CLS) Child Marriage Project funded by Ford Foundation. I am grateful for the guidance of the Principal Investigator, Dr. Kelley Moult. However, the opinions expressed in this article do not necessarily reflect the views of CLS nor Ford Foundation. 


\section{INTRODUCTION}

In what ways can the clash between cultural autonomy and child marriage prohibition be addressed? Ordinarily, a child should be a person who, in some fundamental way, is not yet developed, but is in the process of developing. ${ }^{1}$ However, the definition of a child remains inconsistent, ambiguous, and varying according to countries, circumstances, regions and communities. It also varies based on the applicable nature of law. For example, there are varying definitions of a child, age of marriage, and age of consent under marriage laws, criminal laws, juvenile justice, child protection, and contract laws. Over time, the definition of a child has undergone and is undergoing review by governments through constitutional amendments, since the constitution is the supreme law in most states. For example, the Malawian constitution, with regards to age of marriage, was amended to bring uniformity in the definition of a child and to close loopholes that allow children between the ages of 15 and 18 years to get married with parental consent. The amendment was also to align the Constitution with other statutory laws such as the Marriage, Divorce and Family Relations Act, a law that sets 18 as the age of marriage. ${ }^{2}$ On 20 January 2016, the Zimbabwean constitutional court struck off section 22(1) of the Marriage Act, which allowed children under the age of 18 to marry. The Justices of the court ruled that the provision is inconsistent with the Zimbabwean Constitution. The court ordered that "No person, male or female, in Zimbabwe may enter into any marriage, including an unregistered customary law union or any other union, including one arising out of religion or a religious rite, before attaining the age of eighteen (18)". ${ }^{3}$ The Zimbabwean Parliament is also set to pass a new law that would see parents arrested for accepting lobola (brides-price) for children younger than $18{ }^{4}$ The Zimbabwean Customary Marriage Act, which is silent on the age of marriage, shall have an insertion stating that no person under the age of 18 shall be capable of contracting marriage. ${ }^{5}$ On February 2015, the Malawian parliament passed the Marriage, Divorce and Family Relations Act (Bill No. 5 of 2015). ${ }^{6}$ The Act increases the legal age of marriage to 18 and punishes the perpetrators of child marriage. Recently, legal drafters from the Southern African Development Community (SADC) approved and adopted a regional Model Law on Eradicating Child Marriage. ${ }^{7}$ The Model Law aims to eradicate child marriage and protect children already in marriage. Countries in the SADC region such as Zambia and Mozambique are working towards aligning their Marriage laws as well as their constitution to the Model law. ${ }^{8}$ Nonetheless, these changes have not eliminated

1 Schapiro, T., What Is a Child? Ethics, Vol. 109, No. 4, 1999, pp. 715-738, p. 716.

2 Masina, L., Malawi Outlaws Child Marriage, 2017, https://www.voanews.com/a/malawi-outlaws-child-marriage/3824898.html. Accessed 10 October 2017.

3 UNICEF, The Constitutional Court Ruling on ending Child Marriages: An Important First Step, https://www.unicef.org/zimbabwe/ media_17754.html. Accessed 29 September 2017.

$4 \quad$ Ibid.

5 Ibid.

6 Human Rights Watch, Malawi: New Marriage Law Can Change Lives, https://www.hrw.org/news/2015/04/17/malawi-newmarriage-law-can-change-lives. Accessed 30 September 2017.

7 SADC Parliamentary Forum, https://www.girlsnotbrides.org/wp-content/uploads/2016/10/MODEL-LAW-ON-ERADICATINGCHILD-MARRIAGE-AND-PROTECTING-CHILDREN-ALREADY-IN-MARRIAGE.pdf. Accessed 30 September 2017.

8 National strategies are being adopted in line with this model law. Zimbabwe is set to align its marriage laws and constitution in line with the SADC Model Law. See https://www.newsday.co.zw/2017/03/bill-align-marriage-laws-constitution/. Accessed 7 October 2017. 
existing disparity on the definitions of a child. For example, despite the passing of the Marriage, Divorce and Family Relations Act in 2015 in Malawi, there is still an outcry that section 14 of the Act conflicts with the Constitution with regards to the age of marriage. ${ }^{9}$ This unclear definition of a child especially on the issue of marriage and the total disregard for the consequences attached to it contributes to violations of human rights.

\section{UNDERSTANDING THE PROBLEM}

Child marriage, a global menace and violation of human rights, cuts across all countries, cultures, regions, religions and ethnicities. ${ }^{10}$ The term 'child marriage' here means a formal marriage or informal union before the age of $18 .^{11}$ The formal marriage is a marriage allowed by the law, such as Constitution and other statutory laws while informal marriage means marriage without the backings of the law such as customary law marriage which is largely uncodified. ${ }^{12}$ Child marriage robs children of the opportunity to enjoy childhood and experience dependence, protection, and care from their respective families. ${ }^{13}$ It also affects their health, sexual, social and psychological development. ${ }^{14}$ It turns them into protectors, nurturers, and providers. Children are shoved with the responsibility of being parents through child marriage, thus removing demarcation between the role and responsibility of an adult and a child. As a prevalent practice, child marriage has defied legislation in most Southern Africa. Given that children are ill-prepared for marriage and its concomitant elements such as sex, psychological, emotional and physical maturity to be spouses and possibly parents, this paper argues that the journey to self-discovery and identity is at the intersection of culture, law, and religion. The clash between religious and cultural autonomy is a pervasive problem for national and international laws, one that arises because of claims of immunity from child protection and marriage provisions on the grounds of cultural or religious autonomy. Using literatures and examples from few countries in Southern Africa, this article addresses this problem using a legal pluralist perspective. This perspective seeks to bridge the gap between customary law, national laws, and international treaties, and requires sensitivity to the economic and socio-cultural factors behind the persistence of child marriage.

This article is divided into four parts. Following introduction and problem background, third part reviews the concept of child, identity and child marriage. It looks at the importance

9 On $14^{\text {th }}$ February 2017, the parliament passed a landmark bill to amend the Constitution and harmonise the age of a child with other relevant laws.

10 Wadesango, N., Rembe, S and Chabaya, O., Violation of Women's Rights by Harmful Traditional Practices Anthropologist, Vol. 13, No 2, 2011, pp. 121-129 at 124-125; Warner, E., Behind the Wedding Veil: Child Marriage as a Form of Trafficking in Girls, American University Journal of Gender, Social Policy and the Law, Vol. 12, No. 2, 2004, pp. 233 - 272, p. 239.

11 Raj, A., When the mother is a child: the impact of child marriage on the health and human rights of girls, Archives of Disease in Childhood, Vol. 95, No. 11, 2010, pp. 931-935, p. 931.

12 Wanda, BP., Customary family law in Malawi: Adherence to tradition and adaptability to change, The Journal of Legal Pluralism and Unofficial Law, Vol. 20, No. 27, 1988, pp. 117-134, p. 119.

13 Rutter, M., Parent-Child Separation: Psychological Effects on the Children, Journal of Child Psychology and Psychiatry Vol. 12, No. 4, 1971, pp. 233-260, p. 233. 
of family support versus the lack of it on a child. It situates this loss of identity to lack of family support. Part four identifies state efforts to combat and harmonise laws on child rights and prevent child marriages. It will further highlight the challenges faced in combating this menace. Fifth part conceptualises cultural relativism. This part situates the challenges faced in combating the widespread of child marriage practice and problem of loss of identity to the clash between cultural autonomy and law. It then argues that the journey to self-discovery and identity is at the intersection of culture, law, and religion. Final part draws a causal link between the prevalence of child marriage and normative interaction.

\section{CONCEPTUALISING CHILD, CHILD MARRIAGE AND IDENTITY}

Childhood is a natural and universal period of transition to adulthood. ${ }^{15}$ However, what or who is a child is an important question that is rarely asked because it seems to be irrelevant. ${ }^{16}$ The term child which in Latin means infans, is defined as a person who is inarticulate, immature and needs protection. ${ }^{17}$ African Charter on the Rights and Welfare of the Child (ACRWC) defines a child as every human being below the age of 18 years. ${ }^{18}$ Article 1 of the Convention on the Rights of the Child (CRC) of 1989 defines a child as any human being below the age of eighteen years, unless under the law applicable to the child, majority is attained earlier. Most national constitution and statutes have their definition and set legal age of who is a child. ${ }^{19}$

The inconsistency surrounding the meaning of a child both legally and culturally is the most striking and problematic aspect of the concept. This is because the conception of the child is wide and the age of the majority varies from time to time, space to space and from one culture to another. ${ }^{20}$ Age of majority here means the legally fixed threshold of adulthood. At this point, a child ceases to be considered a child and assumes the legal control over their persons, actions, decisions thus terminating parental control and legal responsibilities over them. For time conception of a child, Ariès in his child development theory argued that in the medieval period, childhood did not exist but was rather closely linked to adulthood, adolescence and seen as a period of independence. ${ }^{21}$ Scholars such as Luker have argued that the concept

15 James, A., C Jenks, C., Prout, A., Theorizing Childhood, 1998, pp. 5-10; Jenks, C., Childhood, 1996, pp. 7

16 This is because it means different things to different people. See C Jenks, op. cit. note 15, p. 6 -7; James, A., Prout, A., Constructing and Reconstructing Childhood: Contemporary Issues in the Sociological Study of Childhood, 2015, p. 2

17 Piaget, J., The Language and Thought of the Child, 1959, $3^{\text {rd }}$ ed, pp. 1-14; Cunningham, H., Children and Childhood in Western Society since 1500, 1995, p. 1

18 Article 2 of ACRWC 1990.

19 For example, see The Children's Act of 2005 (Act No. 38 of 2005) Interpretation; Sec 28 (3) South African Constitution 1996; Sec 266 Constitution of Zambia (Amendment) Act 2016.

20 James, A., From the child's point of view: Issues in the construction of childhood in: Panter-Brick, C. (ed.), Biosocial perspectives on children, 1998, pp. 47, 62.

21 Ariès, P., Centuries of Childhood in Beck, J., Jenks, C., Keddie, N., and Young, MFD. (eds.), Toward a New Sociology of Education, 1976, pp. 37-47; see also Veerman, PE., The Rights of the Child and the Changing Image of Childhood, 1992, pp. 3-4. 
of adolescence was introduced in the twentieth century by the move of global economy and society. ${ }^{22}$ For instance, the puberty emergence signals the termination of childhood. ${ }^{23}$

Consequently, it can be argued that the conception of a child is no longer perceived as a natural/universal group but is subject to legal and socio-cultural context. ${ }^{24}$ This is because the experiences of children are different across the globe. ${ }^{25}$ Sociocultural construction and perception of who is a child occurs when there is transformation or alteration (socio-economic conditions) that directly or indirectly affects a large segment of that population or community. These socio-economic changes such as cash economy, cost of migration, global warming and a shift from subsistence form of agriculture to commercial form, brought about a shift from communalism to individualism thus influencing behaviour and decisions. ${ }^{26}$ Furthermore, structural adjustments programmes, western education and religion brought about distortion in practices such as marriage systems such as bridewealth payment. ${ }^{27}$ The result is high demand of bridewealth payment and high incidence of child marriage.

Child marriage as violation of human rights has been a subject of global concern. ${ }^{28}$ Literature on child marriage has grown significantly over the past decade. Studies have shown that child marriage exists to a great significant as a traditional practice in rural areas and amongst people living in poverty. ${ }^{29}$ The main driver of high rates of child marriage is the level of socio-economic development in many countries. ${ }^{30}$ As such the need for survival pushes most

22 Luker, K., Dubious Conception: The Politics of Teenage Pregnancy, 1996, pp. 25, 28-29; Caldwell, JC., Caldwell, P., Caldwell, BK., Pieris, I., The Construction of Adolescents: Implications for Sexuality, Reproduction, and Marriage, Studies in Family Planning, Vol. 29, No. 2, 1998, pp. 137-153; James et al., op. cit. note 15, p. 2.

23 Macleod, C., Teenage Pregnancy and the Construction of Adolescence: Scientific Literature in South Africa, Childhood, Vol. 10, No. 4 2003, pp. 419-437, pp. 421.

24 Bridgeman, J., Monk, D., Introduction: reflections on the relationship between feminism and child law, in Bridgeman, J., Monk, D. (eds.), Feminist Perspectives on Child Law, 2000, p. 3; Beck, J., et al., op. cit. note 21, pp. 5-7; Jenks, C., Editorial: Many Childhoods, Childhood Vol. 11, No. 1, 2004, 5-8 pp. 6; Leshan, EJ., The conspiracy against childhood, 1968, pp. 6 -8; Bain, WE., With life so long, why shorten childhood, Childhood Education, Vol. 38, No. 1, 1961, pp.15-18; Jenks, C., Constructing Childhood Sociologically in Kehily, MJ., (ed.) An Introduction to Childhood Studies, 2009, pp. 93-95.

25 Jenks, C., op. cit. note 15, pp. 6 -7; Stephens, S., Children and the Politics of Culture, 1995, p. 5

26 Berry, S., Cocoa, custom, and socio-economic change in rural Western Nigeria, 1975, pp. iv - xiii; PE Kigho, PE., Global warming and its implication on the economy: the Nigerian perspective, Journal of Research in Peace, Gender and Development, Vol. 3, No. 4, 2013, pp. 54-57, p.55; Jegede, AE., Idowu, AE., Youth at Crossroads: The Challenges of Social Change in Nigeria, Journal of Cultural Studies Vol. 2, 2009, pp. $184-196$ at 184. This is not peculiar to Nigeria see Wolpe, H., Capitalism and cheap labour-power in South Africa: From segregation to apartheid, Economy and society Vol. 1, No. 4, 1972, pp. 425-456, pp. 425-427.

27 Ferraro, G., Andreatta, S., Cultural Anthropology: An Applied Perspective, 2014, pp. 224-225.

28 Child marriage affects both girls and boys but most children married under 18 years of age are girls. See Rembe, S., Chabaya, O., Wadesango, N., and Muhuro, P., Child and Forced Marriage as Violation of Women's Rights, and Responses by Member States in Southern African Development Community, Agenda Vol. 87, No. 25/1, pp. 65-74, p.65; Birechi, J., Child Marriage: A Cultural Health Phenomenon, International Journal of Humanities and Social Science Vol. 3, No. 17, pp. 97-103, p. 98.

29 Bunting, A., Stages of Development: Marriage of Girls and Teens as an International Human Rights Issue, Social and Legal Studies, Vol. 14, No. 1, 2005, pp. 17-38, p. 25; Walker, JA., Early marriage in Africa-trends, harmful effects and interventions, African Journal of Reproductive Health Vol. 16, No. 2, 2012, pp. 231-240, p. 231; Singh, S.,, Samara, R., Early Marriage among Women in Developing Countries, International Family Planning Perspectives Vol. 22, No. 4, 1996, pp. 148-175 at 148; Jensen, R., and Thornton, R., Early Female Marriage in the Developing World, Gender \& Development Vol. 11, No. 2, 2003, pp. 1-19, pp. 1 -11.

3o Ibhawoh, B., Between Culture and Constitution: Evaluating the Cultural Legitimacy of Human Rights in the African State, Human Rights Quarterly, Vol. 22, No. 3, 2000, pp. 838-860, p. 841; Ndulo, M., African Customary Law, Customs, and Women's Rights, Indiana Journal of Global Legal Studies Vol. 18, No. 1, 2011, pp. 87-120, p. 117. 
poor households to give their girl-child out in marriage. ${ }^{31}$ This practice is an economic surviving approach which reduces the number of persons to feed in the household, and also reduces the cost of raising daughters or sending them to school. ${ }^{32}$

Secondly, child marriage is deeply rooted in cultural values and practices. ${ }^{33}$ Culture shapes peoples' behaviour and commands their respect. ${ }^{34}$ Most times, the need to preserve age long tradition/ perceptions also encourages high rates of early marriage. ${ }^{35}$ Most families are under pressure to conform to some certain customary requirements; failure of which can lead to ridicule or family shame. ${ }^{36}$ An example of some tradition that promotes child marriage can be seen in the practice of $u$ kuthwala (forced marriage or marriage by abduction) notable amongst the Eastern Cape of South Africa. ${ }^{37}$ Also the rites of passage ceremonies in which girls as young as eight are compelled to attend customary rites that "teach" them what it means to be a woman and what it entails to be a woman promotes child marriage. ${ }^{38}$

Thirdly, patriarchal ordering contributes to child marriage. ${ }^{39}$ This point also contributes to gender inequality. ${ }^{40}$ Studies have shown that the institution of patriarchy lies in the socialization of the child practice whereby the boy child is taught how to be in control and the girl-child how to be submissive, making them (girl-child) 'traditional underdogs'. ${ }^{41}$ Studies have also shown that child marriage still persists because of the low value given to women and girls. ${ }^{42}$ The families who engage in this practice consider it a way to secure their child's future without

31 Ending child marriage in Africa a brief by Girls Not Brides, available online at http://www.girlsnotbrides.org/wp-content/ uploads/2015/02/Child-marriage-in-Africa-A-brief-by-Girls-Not-Brides.pdf (accessed on 22 June 2015). Otoo-Oyortey, N., Pobi, S., Early Marriage and Poverty: Exploring Links for Policy and Programme Development, Gender and Development, Vol. 11, No. 2, 2003, pp. 45-51, p. 44. Mikhail, SL., Child Marriage and Child Prostitution: Two Forms of Sexual Exploitation, Gender and Development, Vol. 10, No. 1, 2002, pp. $43-49$, p. 43. Landes, D., Culture makes almost all the difference in: Harrison, LE., SP Huntington, SP. (eds.), Culture matters: How values shape human progress, 2000, pp. 2-3, 14-15, 80, 282.

35 UNICEF, Early Marriage a Harmful Traditional Practice: A statistical exploration, 2005, pp. 4.

36 Kanyangu, RM., Factors which contribute to early marriage among teenagers in rural areas in Kasulu District Council (LLM Diss. Submitted to The Open University of Tanzania, 2014) 14.

37 Mwambene, L., Sloth-Nielsen, J., Benign accommodation? Ukuthwala, 'forced marriage' and the South African Children's Act, African Human Rights Law Journal Vol. 11, No. 1, 2011, pp. 1-22, p. 3; Rice, K., Ukuthwala in Rural South Africa: Abduction Marriage as a Site of Negotiation about Gender, Rights and Generational Authority among the Xhosa, Journal of Southern African Studies Vol. 40, No. 2, 2014, pp. 381-399; Bekker, JC., Rautenbach, C., Goolam, N., Introduction to legal pluralism in South Africa, 2006, p. 31. Many scholars have shown that this practice does not amount to forced marriage because of the meaning attached to it. See Koyana, DS., Bekker, JC., The Indomitable Ukuthwala Custom, De Jure Vol. 40, No. 1, 2007, pp. 139-144, p. 140; Bennett, TW., Customary Law in South Africa, 2004, p. 201.

38 Linton, R., Age and Sex Categories, American Sociological Review, Vol. 7, No. 5, 1942, pp. 589-603, p. 598; Zabin, LS., Kiragu, K., The Health Consequences of Adolescent Sexual and Fertility Behavior in Sub-Saharan Africa, Studies in Family Planning, Vol. 29, No. 2, 1998, pp. 210-232, pp. 214-215.

39 Mfono, Z., The custom of bride abduction holds its own against time, Agenda Vol. 16, No. 45, 2000, pp. 76-80; Maluleke, TS., Nadar, S., Breaking the Covenant of Violence against Women, Journal of theology for Southern Africa Vol. 114, 2002, pp. 5-17, p. 14; Mathur, SM., Malhotra, GA., Too Young to Wed: The Lives, Rights, and Health of Young Married Girls, 2003.

40 Raj, A., When the mother is a child: The Impact of Child Marriage on the Health and Human Rights of Girls Archives of Disease in Childhood Vol. 95, No. 11, 2010, pp. 931-935, p. 931.

41 Mfono., op. cit. note 39, p. 76; Richter, L., Dawes, A., C Higson-Smith., (eds.) Sexual Abuse of Young Children in Southern Africa, 2004, p. 102-103. 
paying attention to the effects it has on the child. ${ }^{43}$ In what follows, this article will situate lost identity as an effect of child marriage.

\subsection{LOST IDENTITY IN THE CONTEXT OF CHILD MARRIAGE}

Before looking at the effects of child marriage on the child it is worthy to note that child marriage varies depending on society's view of the role, structure, pattern, individual and collective responsibilities of every member of the family. Family is the foundation of social life in human societies. It is a major institution tasked with the responsibility of social and economic empowerment, reproduction of society both socially and otherwise, protection and guidance. As such its influence on child's personality development cannot be over emphasised. The foundation of family in most traditional societies is marriage whether monogamous or polygamous. ${ }^{44}$ Marriage and family are key structures in most societies. Consequently, when families engage or force their girl child to early marriage it causes psychological breakdown/ distress. ${ }^{45}$ It also impedes on the health, sexual, social, emotional and psychological development of the victim. ${ }^{46}$ Since most of child marriages are without the free and full consent of the girl who most times lack the decision-making powers and skills to be mothers and wives, they are forced to become adults. ${ }^{47}$ These children grow up as a child without childhood. The result is that after marriage these children become isolated from society, develop low self-esteem, lose their self-worth and identity. ${ }^{48}$ The reason is that most of these girls who marry before the age of 18 have low educational level, lack access to information on sex and use of contraceptives, they are also forced into sexual activity despite the fact they are ill prepared for it. ${ }^{49}$ Efforts have therefore been put in place by government to put to an end to the incessant increase of child marriage. In what follows this article will examine the efforts of government to end child marriage and challenges encountered in the intervention.

43 Scheper-Hughes, N., Child Survival: Anthropological Perspectives on the Treatment and Maltreatment of Children, 1987, pp. 254-255.

Dobson, J.C., Marriage is the Foundation of the Family, Notre Dame Journal of Law, Ethics \& Public Policy, Vol. 18, No. 1, 2004 pp. 1-6, p. 1; Armstrong, A., Beyani, C., Himonga, C., Kabeberi-Macharia, J., Molokomme, A., Ncube, W., Nhlapo, T., Rwezaura, B., Stewart, J., Uncovering reality: excavating women's rights in African family, International Journal of Law, Policy and the Family Vol. 7, No. 3, 1993, pp. 314-369, p. 318, pp. 328-329.

45 Veerman., op. cit. note 21, p. 361.

46 Ashworth, G., Of Violence and Violation: Women and Human Rights, 1986, Change International Reports; B Charlotte, B., The Intolerable status quo: Violence against Women and Girls, The Progress of Nations, Vol. 1, 1997, pp. 40-49 p. 41- 45.

47 Ouattara, M., Sen, P., Thomson, M., Forced Marriage, Forced sex: The Perils of Childhood for Girls, Gender and Development Vol. 6 , No. 3, 1998, pp. 27-33, p. 28; Nkosi, M., Wassermann, J., A history of the practice of ukuthwala in the Natal/KwaZulu-Natal region up to 1994, New Contree, Vol. 70, 2014, pp. 131-146, p. 142.

48 Identity has been defined as a search for the authentic self. See Taylor, C., The Ethics of Authenticity, 1992, p. 44.

49 Clark, S., Bruce, J., Dude, A., Protecting Young Women from HIV/AIDS: The Case against Child and Adolescent Marriage, International Family Planning Perspectives, Vol. 32, No. 2, 2006, pp. 79-88, p. 79 


\section{INTERVENTIONS TO END CHILD MARRIAGE}

Efforts, strategies, policies, programs, laws by both international and national government have been put in place to stop this social anomaly..$^{50}$ These international treaties and conventions include but not limited to article 21 (1) and (2) of the African Charter on the Rights and Welfare of the Child 1990, ${ }^{51}$ article 19(1) and (2) of the Convention on the Rights of the Child 1989, article 8(1) and (2) of the SADC Protocol on Gender and Development 2008,52 article 16(1) and (2) of the UN Convention on the Elimination of all forms of Discrimination against Women (CEDAW) 1979,,$^{53}$ article 10 (1) of the International Covenant on Economic, Social and Cultural Rights (ICESCR) 1966, ${ }^{54}$ article 23 (2), (3) and (4) of the International Covenant on Civil and Political Rights (ICCPR) 1966, ${ }^{55}$ article 16 (a) and (b) of the Universal Declaration of Human rights (UDHR) 1948. Country interventions include but not limited to South African Law Reform Commission (SALRC) Revised Discussion Paper on Project 138: The Practice of Ukuthwala. Studies have shown that the success of this intervention and many other programs geared toward ending child marriage can and have been hampered by so many factors/ challenges.

The first is the issue of imposing foreign culture on non-western societies. According to Bunting, most programs, strategies are bound to fail if it is perceived by the recipients as a means to import foreign values/culture or an attempt to regulate population growth. ${ }^{56}$ Explaining further she said that if communities do not see early marriage as a human rights violation, many programmes aimed at stopping it may be seen as imposition of western/foreign values regarding marriage on non-western societies. ${ }^{57}$ It is worthy to note that culture gives people a sense of belongings, as such it is difficult to let go of most of its belief..$^{58}$

The second challenge is patriarchy. The issue of patriarchy also poses a barrier to the success of child marriage programs. When people believe that the programs will empower women or girls to challenge their husbands, then it becomes very difficult to implement the programs. This empowerment can come in the form of education for the girls, the result is that women can become self-reliant and aware of their rights. Consequently, they are denied the privilege of going to school.

50 See for example Marriage, Divorce and Family Relations Act (Bill No. 5 of 2015).

51 African Charter on the Rights and Welfare of the Child, OAU Doc. CAB/LEG/24.9/49 (1990), entered into force Nov. $29,1999$.

52 SADC Protocol on Gender and Development, 2008, entered into Force February 22, 2013.

53 The UN Convention on the Elimination of all forms of Discrimination against Women (CEDAW) adopted in 1979 and came into force on 3 September 1981.

54 International Covenant on Economic, Social and Cultural Rights (ICESCR) adopted on 16 December 1966, and entered into force from 3 January 1976.

55 International Covenant on Civil and Political Rights (ICCPR), adopted on 16 December 1966, and entered into force from 23 March 1976.

56 Bunting, op. cit. note 29, p. 27.

57 Bunting, op. cit. note 29, p. 33. See also by Fenrich, J., Galizzi, P., Higgins, TE., The Future of African Customary Law, 2011, p. 213.

58 Wadesango, et al, op. cit. note 10, p. 121; see also AE Iyanuolu, AE., The challenges of culture for the rights of women in Africa: A critical analysis of the protocol to the African charter on human and people's rights on the rights of women in Africa, 2008, LLM thesis UCT. 
The third challenge relates to the suitability of the program to address the condition of the girls in question. According to Bridgeman and Monk, most programmes and policies are not culturally suitable to address the socio-economic conditions in which girls and young women live. ${ }^{59}$ According to them, the consequences and reason for child marriage might differ from place to place and time due to cultural factors. ${ }^{60}$ Burr in agreement to this suggests that real changes will only take place if close attention and respect is shown for cultural beliefs and practices of local people, including children. ${ }^{61}$ Kabeberi-Macharia argues in line with Bridgeman et al that most programmes are not culturally appropriate to address the socio-economic conditions of the girl-child because they fail to show an understanding of the status of the girl-child, the cultural norms, attitudes and economic activities of the community she comes from and how these have been shaped by social and economic factors. ${ }^{62}$ Freeman also suggests that child's rights be expressed in a universal term but applied in a way that is responsive to the local context. ${ }^{63}$ This issue was also raised by Lowe and Douglas when they suggested that regional approach rather than a global approach should be adopted towards and if success to child marriage programs is to be achieved. ${ }^{64}$ Arango et al also argues that careful understanding of the cultural context within which these practices take place must be looked into for successful child marriage programs. ${ }^{65}$

The fourth challenge is legal pluralism. The term is defined as the existence of multiple legal systems within one legal field, human population and/or geographic area. ${ }^{66}$ Gaffney-Rhys notes that legal pluralism which is prevalent in most African countries hampers the success of child marriage programs. ${ }^{67}$ This issue of legal pluralism according to her is of two types; the first one involves the co-existence of international treaties and national laws. An example is the article 16(2) of the Convention on the Elimination of all forms of Discrimination against Women (CEDAW) which states that ' $t$ ] he betrothal and the marriage of a child shall have no legal effect...' but failed to define who a child is. It merely provides that States fix the age without any suggestion. Also, article (1) of the Convention on the Rights of the Child (1989) clearly defines a child as a person below the age of eighteen (18). Also, the UN General Assembly adopted the resolution that minimum age for marriage should not be less than fifteen (15) during its twentieth session in $1965 .{ }^{68}$ The African Charter on the Rights and Welfare of the Child (ACRWC) 1990 also stipulates that minimum age for marriage is 18, countries like Mozambique permits that girls be married at the age of 14 . The implication of this is that some

59 Bridgeman, op. cit. note 24, p. 3

60 Bridgeman, op. cit. note 24, p. 3. See also James et al, op. cit. note 15, p. 58; Bunting, A., Particularity of rights, Diversity of contexts: Women, International Human Rights and the Case of Early Marriage, 1999, PhD diss., National Library of Canada, p. 11.

61 Burr, R., Global and Local Approaches to Children's Rights in Vietnam, Childhood Vol. 9, No. 1, 2002, pp. 49-61, p. 49, p. 60.

62 Kabeberi-Macharia, J., Reconstructing the Image of the Girl-Child in Ncube, W. (ed.), Law, Culture, Tradition and Children's Rights in Eastern and Southern Africa, 1998, p. 47.

63 Freeman, M., Culture, Childhood and Rights, Family in Law Review Vol. 5, 2011, pp. 15-33, p. 22.

64 Lowe, N., Douglas, G., Bromley's Family Law, 2015, p. 24.

65 Arango, DJ., Morton, M., Gennari, F., Kiplesund, S., and Ellsberg, M., Interventions to prevent or reduce violence against women and girls: A systematic review of reviews, Women's Voice and Agency Research Series Vol. 10, 2014, pp. 1-60, p. 27.

66 Griffiths, J., What is legal pluralism? The Journal of Legal Pluralism and Unofficial Law Vol. 18, No. 24, 1986, pp. 1-55, p. 38.

67 Gaffney-Rhys, R., International Law as an Instrument to combat Child Marriage, The International Journal of Human Rights Vol. 15, No. 3, 2011, pp. 359-373, pp. 364-365. 
countries find it problematic to ascertain age at marriage, partly because they either ratified the UN recommendation or CEDAW or the ACRWC. Secondly is the issue of recognition/acceptance of national laws and personal laws by many countries. Most national laws exist in conjunction with personal laws which allows marriage at a far earlier age. An example is the Muslims, who are subject to the sharia law which does not stipulate any specific age. ${ }^{69}$ Kuenyehia in agreement with Gaffney-Rhys said that the interaction of these laws often result in conflict, abuse and denial of rights. ${ }^{70}$ Himonga also argues that the application of customary law together with the state laws lead to conflict as such, it can affect the implementation of conventions. ${ }^{71}$

The fifth challenge is culture and complexity of government procedures. People's dependence on their tradition slows down the implementation of convention and international treaties. According to the surveys taken by the World Bank's Institutional Reform and Capacity Building Project (IRCBP), rural people see the customary legal system as the main source of authority because it is more accessible and the most influential in their lives; they trust their traditional leaders more than they trust the formal government because they are more familiar to them; they are more likely turn to traditional chiefs and local courts to settle their disputes than they are to turn to formal government bodies like police units and courts. ${ }^{72}$ While most victims of early child marriage prefer to settle the problem amongst their local communities or NGOs, the formal system like the court doesn't help matters as most of their procedures are lengthy, complicated, expensive, and foreign, it also takes time to achieve desired result. ${ }^{73}$

The sixth challenge is lack of skill/ expertise and awareness. Most of the traditional authorities, law enforcement officials are not well trained or aware of child marriage, its ills and legal prohibition making most of the cases of early child marriage unreported. ${ }^{74}$ Lack of skills and capacity has been noted to be a barrier to the effective functioning of child marriage programs. According to a report on Stamping out and Preventing Gender-Based Violence and Child Marriage, the Ministry of Chiefs and Traditional Affairs (MCTA) in Zambia has taken a strong lead on tackling child marriage, launching a campaign to end child marriage (ECM) in April 2013 which has, to date, increased media coverage, and conducted provincial sensi-

69 de Alwis, RS., Child Marriage and the law-legislative Reform Initiative Paper series, 2008, p. 30; Nkoyo, T., Revising equality as a right: The minimum age of marriage clause in the Nigerian child rights 2003, Third World Quarterly Vol. 27, No. 7, 2006, pp. 1299-1312, p. 1299; see also Himonga, C., The Right of the Child to Participate in Decision Making: A Perspective from Zambia in Ncube, W., (ed.) Law, Culture, Tradition and Children's Rights in Eastern and Southern Africa, 1998, p. 96. See a similar situation in India; MacKinnon, CA., Sex equality under the Constitution of India: Problems, prospects, and personal laws, International Journal of Constitutional Law Vol. 4, No. 2, 2006, pp. 181-202, p. 181.

70 Kuenyehia, A., Women, Marriage, and Intestate Succession in the Context of Legal Pluralism in Africa, University of California Davis Law Review Vol. 40, No. 2, 2006, pp. 385-405, pp. 385-388.

71 Himonga, C., The Application of African Customary Law under the Constitution of South Africa: Problems Solved or just Beginning?' South African Law Journal Vol. 117, No. 2, 2000, pp. 306-341, p. 306.

72 (IRCBP) Institutional Reform and Capacity Building Project Evaluations Unit, 'Report on the IRCBP 2007 National Public Services Survey: Public Services, Governance, Dispute Resolution and Social Dynamics' (2008) 35; see also V Maru, V., Between Law and Society: Paralegals and the Provision of Justice Services in Sierra Leone and Worldwide, Yale Journal of International Law, Vol. 31, No. 2, 2006, pp. 476 - 427, pp. 448-449.

73 Plan International United Kingdom, 'Before their time: Challenges to Implementing the Prohibition against Child Marriage in Sierra Leone', 2013, pp. 27-30.

74 Lowenstein clinic interview with William Bangura, Principal Social Development Officer, Ministry of Social Welfare, Gender and Children's Affairs, National Government of Sierra Leone, Makeni 2012. 
tisation workshops with traditional chiefs but it (MCTA) has limited technical capacity. ${ }^{75}$ The empowerment of Chiefs/traditional leaders will go a long way in mitigating child marriage. Recently, a chief in Malawi annulled 330 customary marriages - of which 175 were girl wives and 155 were boy fathers. ${ }^{76}$ Bunting also notes that the available laws and policies are not being complied with because people are not aware of their existence. ${ }^{77}$

The seventh challenge is the domestication of international treaties and inaccessibility of most child marriage centres. Jonas highlights that the issue of ratification of international treaties can mitigate the success of child marriage programs. ${ }^{78}$ According to him, international treaties are not self-executing and will only be a noble declaration if not domesticated. He suggested the need for them to be domesticated locally either through making of a new law or adjusting existing laws to conform to the requirements of the instrument. Jonas also raised the issue of inaccessibility of most NGO's, and other institutions that work to eradicate child marriage ${ }^{79}$ According to him, most of the NGO's are located in the urban areas making it difficult for children in the rural areas to access the available facilities.

The eighth challenge to the success of child marriage programs is the issue of funding. Most programs depend on international communities, government and other donors for its success. ${ }^{80}$ Financial assistance and basic supplies like vehicles and writing supplies seems to be inadequate, making plans for eradication of early child marriage unrealisable.

From its findings in Sierra Leone, Plan International reported that the lack of funding is mostly because the government lack the political will to end child marriage. ${ }^{81}$ Government has not made child marriage its priority, as such allocating resources to end it may be more than a mirage..$^{82}$

The ninth challenge faced in effective programming and policy regarding child marriage is the fact that most marriages are unregistered and unofficial as such very little data exist about child marriage. ${ }^{83}$

The tenth challenge relates to the fact that most human right programs deal with the individual rather than the group. As Bennet put it, human rights emphasize the individual while customary law emphasizes the group or community; customary law stresses duties, human rights regimes naturally stress rights; and customary law is imbued with the principle of pa-

75 Business Case: Stamping out and Preventing Gender-Based Violence and Child Marriage available online at iati.dfid.gov.uk/iati documents/4317633.doc. Accessed on the 19 July 2015.

76 UN Women, Malawi Chief annuls 330 child marriages, 2015, http://www.unwomen.org/en/news/stories/2015/9/malawi-chiefannuls-330-child-marriages. Accessed 14 October 2017. Bunting op. cit. note 29, p. 27; Gaffney-Rhys op. cit. note 67, p. 369.

Jonas, B., Towards Effective Implementation of Children's Rights in Tanzania: Lessons and opportunities from Ghana and South Africa, Master's thesis, university of Pretoria, 2006, p. 16; see also Rhezaura, B., Domestic Application of International Human Rights Norms: Protecting the Rights of the Girl Child in Eastern and Southern Africa in Ncube, W., (ed.) Law, Culture, Tradition and Children's Rights in Eastern and Southern Africa, 1998, p. 29.

79 Jonas, op. cit. note 78 , p. 27

80 Jonas, op. cit. note 78, p. 27; see also Gaffney-Rhys, op. cit. note 67, p. 369.

81 Plan International UK, op. cit. note 73, p. 30.

82 Nour, op. cit. note 14, pp. 1647.

83 Warner, op. cit. note 10, pp. 237. 
triarchy, which means that any freedoms of thought, speech, movement or association are qualified by the respect due to all senior men. ${ }^{84}$

The eleventh challenge is the issue of the meaning of a child and variations in the age for marriage. Chinyangara et al note that variations in the minimum age for marriage and also the definition and understanding of who a child is can pose a challenge to the success of programs. ${ }^{85}$ Ariès accepts that there are different variations in understanding and meaning of who a child is, making it difficult to adhere to the provisions of international conventions. ${ }^{86}$ Ncube argues that there exist diverse cultural and traditional ideas of childhood, its role, its rights and obligations that must be put into consideration in the interpretation of children's rights. ${ }^{87}$ Rhezaura argues that the world community is so diverse socially, economically and culturally, as such cannot understand children's rights the same way. ${ }^{88}$ According to him, regional studies/survey should be conducted in order to ascertain how communities understand and apply children's rights, how it defines the relationship of parent and child and what it considers to be appropriate conduct between them and other members of the family. ${ }^{89}$ Affirming the argument of Rhezaura, Himonga notes that proper assessment should be done to ascertain what meaning and understanding the Convention and various treaties means to children and their various families using Zambia as an example. ${ }^{90}$ This challenge relates also to the issue of cultural relativism. The next section will review the concept of cultural relativism. It situates the challenges faced in combating the widespread of child marriage practice and problem of loss of identity to the clash between cultural autonomy by arguing that the journey to self-discovery and identity is at the intersection of culture, law, and religion.

\section{CULTURAL RELATIVISM AND LOSS OF IDENTITY}

The practice of child marriage has developed differently in diverse communities based on different meaning and social context of specific community. ${ }^{91}$ In other words, practice such as child marriage, are sanctioned by the relevant social understandings of the cultures within which they are practiced. In most societies, child marriage persists because of the belief that young girls will engage in premarital sex or get unwanted pregnancy either by choice or by for-

84 Bennett, TW., The Compatibility of African Customary Law and Human Rights, Acta Juridica, 1991, pp. 18- 35, p. 23.

85 Chinyangara, I., Chokuwenga, I., Dete, RG., Dube, L., Kembo, J., Moyo, P., Nkomo, R., Indicators for Children's Rights: Zimbabwe country case study, Zimbabwe, 1997.

86 Ariès, op. cit. note 21, pp. 37-40.

87 Ncube, W., Prospects and Challenges in Eastern and Southern Africa: The Interplay between International Human Rights Norms and Domestic Law, Tradition and Culture in: W Ncube, W. (ed.), Law, Culture, Tradition and Children's Rights in Eastern and Southern Africa, 1998, p. 1.

88 Rhezaura, B., Law, Culture, Tradition and Children's Rights in Eastern and Southern Africa: Contemporary challenges and present-day dilemmas in Ncube, W., (ed.) Law, Culture, Tradition and Children's Rights in Eastern and Southern Africa, 1998, p. 289-290; see also An-Naim, AA., Towards a Cross Cultural Approach to Defining International Standards of Human Rights: The Meaning of Cruel, Inhuman, Degrading Treatment or Punishment' in An-Naim, AA., (ed.) Human Rights in Cross Cultural Perspectives, 1992 , p. 19-20.

89 Rhezaura, op. cit. note 88; see also Rhezaura, B., The Duty to Hear the Child: A View from Tanzania in Ncube, W. (ed.), Law, Culture, Tradition and Children's Rights in Eastern and Southern Africa, 1998, p. 59.

90 Himonga, op. cit. note 69, p. 97. 
ce which might render them (girls) unmarriageable. ${ }^{92}$ This is mostly the case in communities where virginity is valued. ${ }^{93}$ As such they are married early to ensure their virginity. ${ }^{94}$ Other communities, believe that early marriage will derail young girls from engaging in any promiscuous act either for financial purposes or otherwise. ${ }^{95}$ Yet, others engage in child marriage because of the incentives of bridewealth payment. ${ }^{96}$ These examples show that child marriage is relative to the individual community. In other words, the success and failure of child marriage programmes is based on the interest of the community it serves. The term cultural relativism is a principle that holds that some cultural and historical variations are exempt from legitimate criticism by outsiders. ${ }^{97}$ This term is strongly supported by notions of communal autonomy and self-determination. The challenges faced in combating the widespread of child marriage practice and problem of loss of identity relates to the clash between cultural, religious autonomy and state laws. Therefore, restoring the lost identity of children who are engaged in child marriage rests on resolving the tension between law, religion and culture.

\subsection{THE TENSION BETWEEN CULTURE, LAW AND RELIGION: A CASE OF LEGAL PLURALISM}

Legal pluralism is the consequence of colonial rule in Africa. ${ }^{98}$ The concept of legal pluralism recognises religious, customary and other state laws. ${ }^{99}$ Customary law as well as religious law such as Islamic law is entrenched in the community. The application of these laws to practices such as marriage leads to conflict of laws. For instance, family laws which are regulated by customary laws conflicts with provisions of state laws and other international laws. These laws (state laws and international conventions and treaties) create loop hole that allows the application of customary law. In South Africa, section 24 (1) of the Marriage Act states that 'No marriage officer shall solemnize a marriage between parties of whom one or both are minors unless the consent to the party or parties which is legally required for contracting the

92 Warner, op. cit. note 10, p. 239; Nour, op. cit. note 14, p. 1644.

93 Hampton, T., Child marriage threatens girls' health, Jama Vol. 304, No. 5, 2010, pp. 509-510 at 510; Lee-Rife, S., Malhotra, A., Warner, A., Glinski, AM., What works to prevent child marriage: a review of the evidence, Studies in family planning, Vol. 43, No. 4, 2012, pp. 287-303 at 288; Askari, L., The Convention on the Rights of the Child: The Necessity of Adding a Provision to Ban Child Marriages, ILSA Journal of International and Comparative Law Vol. 5, No. 1, 1998, pp. 123-138 at 126; Sohoni, N., The Burden of Girlhood: A Global Inquiry into the Status of Girls, 1995, p. 32-33; O'Connell, H., Women and the Family, 1994, p. 15.

Jensen, et al., op. cit. note 29, p. 9, 12,18; Gaffney-Rhys, op. cit. note 67, p. 360

Warner, op. cit. note 10, p. 241.

Askari, L., op. cit. note 93, p. 126; Saranga, J., Kurz, K., New Insights on Preventing Child Marriage: A Global Analysis of Factors and Programs, 2007, p. 9.

Donnelly, J. 'Cultural Relativism and Universal Human Rights' Human Rights Quarterly, Vol. 6. No. 4, 1984, pp. 400- 419 at 400401; Teson, FR, 'International Human Rights and Cultural Relativism' Virginia Journal of International Law, Vol. 25, No. 4, 1984, pp. 869- 900 at 873; Pollis, A., 'Liberal, Socialist and Third World Perspectives of Human Rights' in: Schwab, P. (ed.), Toward a Human Rights Framework, 1982, pp. 22-23;

8 Merry, SE., 'Legal Pluralism' Law and Society Review, Vol. 22, No. 5, 1988, 869 -896 at 869; Himonga, C., Bosch, C., 'The Application of African Customary Law under the Constitution of South Africa: Problems Solved or Just Beginning' South African Law Journal, Vol. 117, 2000, pp. 306- 341, p. 307.

Higgins, TE., Fenrich, J., Tanzer, Z., Gender Equity and Customary Marriage: Bargaining in the Shadow of Post-Apartheid Legal Pluralism, Fordham International Law Journal, Vol. 30, No. 6, 2007, pp. 1653- 1708 at 1664 
marriage has been granted and furnished to him in writing'. Subsection 2 states that 'For the purposes of sub-section (1) a minor does not include a person who is under the age of twenty - one years and previously contracted a valid marriage which has been dissolved by death or divorce'. ${ }^{100}$ While Sec 3 (3) (a) of the Recognition of Customary Marriages Act 120 of 1998 states that 'If either of the prospective spouses is a minor, both his or her parents, or if he or she has no parents, his or her legal guardian, must consent to the marriage. In Zimbabwe Sec 20 (2) of the Marriage Act states that 'the marriage of a minor shall not be solemnized without the consent in writing of the persons who are, at the time of the proposed marriage, the legal guardians of such minor or, where a minor has only one legal guardian without the consent in writing of such legal guardian'. ${ }^{101}$ Sec 16 (3) of the Zimbabweans' Constitution provides that state and government agencies at all level must ensure due respect of the dignity of traditional institutions. ${ }^{102}$ Article 17 of the Covenant on Civil and Political Rights (CCPR) provides that no one shall be subjected to unlawful or arbitrary interference with his privacy or family. ${ }^{103}$ What is arbitrary and unlawful is not defined. Article 17 (2) went further to state that everyone has the right to the protection of the law against such interference. In most communities and under customary law, age of marriage does not determine capacity to marry. In these communities, puberty signifies the ability of a girl-child her ability to procreate, become a wife and mother. ${ }^{104}$ In the context of child marriage therefore, the implication of this provision (Article 17(2) of CCPR) is that no one should interfere with family issues. In the light of this plural legal settings presented above, these legislations and other human rights provisions contain opportunities, contradictions and loopholes that allows child marriage to strive. It seems therefore, that the success of child marriage programs and laws rest in acknowledging that autonomy revolves around the values and interests of a community. It rests on respecting the meanings attached to the idea of equality, recognising the right of indigenous nations to define and protect their cultural traditions and customs.

\section{CONCLUSION}

Child marriage, a global menace and violation of human rights, cuts across all countries, cultures, regions, religions and ethnicities. It affects both boys and girls. As shown, culture and religion play significant role in shaping the definition, influencing and structuring behaviour around marriage more than law. From the above, it is clear that a number of external and internal factors (socio-economic factors) encourages the prevalence of child marriage, which leads to loss of identity in children. This is despite the efforts made by government and other reformers to end the widespread practice. The practice of child marriage is being challenged and renegotiated by different communities whose interests it serves. So far as these interests

\footnotetext{
100 Marriage Act 25 of 1961

101 Marriage Act [Chapter 5:11].

102 Constitution of Zimbabwe Amendment (Act No.20) Act 2013

103 International Covenant on Civil and Political Rights 1976

104 Rwezaura, B., Competing Images of Childhood in the Social and Legal Systems of Contemporary Sub-Saharan Africa, International Journal of Law, Policy and Family Vol. 12, No. 3, pp. 253- 278 at 260; Armstrong, et al, op. cit. note 44, p. 329
} 
and socio-economic conditions continue to persist, child marriage will continue to be championed by its believers. ${ }^{105}$

It is also clear that child marriage has devastating effects ranging from physical, emotional, health, sexual and social on the girl child. Its persistence is heightened by various socio-economic conditions such as poverty. Consequently, the journey to self-discovery and identity which is at the intersection of culture, law, and religion needs an approach to cultural practice that takes autonomy rather than universalisation as a central guiding principle. The journey to self-recovery also entails a policy dialogue with stakeholders in the community such as the religious and community leaders who have enormous influence in the community. Hence, a bottom-up approach is required to understand and solve the problem of child marriage. This approach requires understanding and being sensitive to people's lived realities that drive child marriage and other societal menace.

\section{REFERENCES}

1. An-Naim, AA., Human Rights in Cross Cultural Perspectives: A quest for consensus, University of Pennsylvania Press, Philadelphia, 1992.

2. Ansell, N., Because it's Our Culture!' (Re)negotiating the Meaning of Lobola in Southern African Secondary Schools, Journal of Southern African Studies, Vol. 27, No. 4, pp. 697-716.

3. Arango, DJ., Morton, M., Gennari, F., Kiplesund, S., Ellsberg, M., Interventions to prevent or reduce violence against women and girls: A systematic review of reviews, Women's Voice and Agency Research Series, Vol. 10, 2014, pp. 1-60.

4. Armstrong, A., Beyani, C., Himonga, C., Kabeberi-Macharia, J., Molokomme, A., Ncube, W., Nhlapo, T., Rwezaura, B., Stewart, J., Uncovering reality: excavating women's rights in African family, International Journal of Law, Policy and the Family, Vol. 7, No. 3, 1993, pp. 314-369.

5. Askari, L., The Convention on the Rights of the Child: The Necessity of Adding a Provision to Ban Child Marriages, ILSA Journal of International and Comparative Law Vol. 5, No. 1, 1998, pp. 123-138.

6. Bain, WE., With life so long, why shorten childhood, Childhood Education, Vol. 38, No. 1, 1961, pp. 15-18.

7. Beck, J., Jenks, C., Keddie, N., Young, MFD., Toward a New Sociology of Education, Transaction books, New Jersey, 1976.

8. Bekker, JC., Rautenbach, C., Goolam, N., Introduction to Legal Pluralism in South Africa, LexisNexis, London, 2006.

9. Bennett, TW., Customary law in South Africa, Kluwer, Cape Town, 2004.

10. Bennett, TW., The Compatibility of African Customary Law and Human Rights, Acta Juridica, 1991, pp. 18- 35.

11. Berry, S., Cocoa, Custom, and Socio-economic Change in Rural Western Nigeria, Clarendon Press, Oxford, 1975.

12. Birechi, J., Child Marriage: A Cultural Health Phenomenon, International Journal of Humanities and Social Science Vol. 3, No. 17, pp. 97-103.

105 Ansell, N., Because it's Our Culture!' (Re)negotiating the Meaning of Lobola in Southern African Secondary Schools, Journal of Southern African Studies, Vol. 27, No. 4, pp. 697-716, p. 715. 
13. Bridgeman, J., Monk, D., Feminist Perspectives on Child Law, Routledge-Cavendish, London, 2000.

14. Bunting, A., Stages of Development: Marriage of Girls and Teens as an International Human Rights Issue, Social and Legal Studies, Vol. 14, No. 1, 2005, pp. 17-38.

15. Burr, R., Global and Local Approaches to Children's Rights in Vietnam, Childhood, Vol. 9, No. 1, 2002, pp. 49-61.

16. Caldwell, JC., Caldwell, P., Caldwell, BK., Pieris, I., The construction of adolescents: Implications for Sexuality, Reproduction, and Marriage, Studies in Family Planning, Vol.29, No. 2, 1998, pp. 137-153.

17. Charlotte, B., The Intolerable status quo: Violence against Women and Girls, The Progress of Nations Vol. 1, 1997, pp. 40-49.

18. Chinyangara, I., Chokuwenga, I., Dete, RG., Dube, L., Kembo, J., Moyo, P., Nkomo, R., Indicators for Children's Rights: Zimbabwe country case study, Zimbabwe, Child-watch International, Harare, 1997.

19. Clark, S., Bruce, J., Dude, A., Protecting Young Women from HIV/AIDS: The Case against Child and Adolescent Marriage, International Family Planning Perspectives, Vol. 32, No. 2, 2006, pp. 79-88.

20. Cunningham, H., Children and Childhood in Western Society since 1500, Routledge, London, 1995.

21. Dobson, JC., Marriage is the Foundation of the Family, Notre Dame Journal of Law, Ethics \& Public Policy Vol. 18, No. 1, 2004, pp. 1-6.

22. Donnelly, J., Cultural Relativism and Universal Human Rights, Human Rights Quarterly, Vol. 6, No. 4, 1984, pp. 400- 419.

23. Fenrich, J., Galizzi, P., Higgins, TE., The Future of African Customary Law, Cambridge University Press, Cambridge, 2011.

24. Ferraro, GP., Andreatta, S., Cultural Anthropology: An Applied Perspective, Nelson Education, Boston, 2014

25. FR Teson, International Human Rights and Cultural Relativism, Virginia Journal of International Law, Vol. 25, No. 4, 1984, pp. 869-900.

26. Freeman, M., Culture, Childhood and Rights, Family in Law Review, Vol. 5, 2011, pp. 15-33.

27. Gaffney-Rhys, R., International Law as an Instrument to combat Child Marriage, The International Journal of Human Rights, Vol. 15, No. 3, 2011, pp. 359-373.

28. Griffiths, J., What is legal pluralism? The Journal of Legal Pluralism and Unofficial Law, Vol. 18, No. 24, 1986, pp. 1-55.

29. Hampton, T., Child Marriage Threatens Girls' Health, Jama Vol. 304, No. 5, 2010, pp. 509-510.

30. Harrison, LE., Huntington, SP., Culture matters: How Values Shape Human Progress, Basic Books, New York, 2000.

31. Higgins, TE., Fenrich, J., Tanzer, Z., Gender Equity and Customary Marriage: Bargaining in the Shadow of Post-Apartheid Legal Pluralism, Fordham International Law Journal Vol. 30, 2007, pp. 1653- 1708.

32. Himonga, C., The Application of African Customary Law under the Constitution of South Africa: Problems Solved or just Beginning?' South African Law Journal, Vol. 117, No. 2, 2000, pp. 306-341.

33. Ibhawoh, B., Between Culture and Constitution: Evaluating the Cultural Legitimacy of Human Rights in the African State, Human Rights Quarterly, Vol. 22, No. 3, 2000, pp. 838-860.

34. James, A., C Jenks, C., Prout, A., Theorizing Childhood, Polity Press, New York City, 1998.

35. James, A., Prout, A., Constructing and reconstructing childhood: Contemporary issues in the sociological study of childhood, Psychology Press, London, 2015.

36. Jegede, AE., Idowu, AE., Youth at Crossroads: The Challenges of Social Change in Nigeria, Journal of Cultural Studies, Vol. 2, 2009, pp. $184-196$.

37. Jenks, C., Childhood, Psychology Press, United Kingdom, 1996. 
38. Jenks, C., Editorial: Many Childhoods, Childhood, Vol. 11, No. 1, 2004, pp. 5-8

39. Jensen, R., and Thornton, R., Early Female Marriage in the Developing World, Gender \& Development, Vol. 11, No. 2, 2003, pp. 1-19.

40. Kehily, MJ., An Introduction to Childhood Studies, Open University Press, Berkshire, England, 2009.

41. Kigho, PE., Global Warming and its Implication on the Economy: the Nigerian Perspective, Journal of Research in Peace, Gender and Development, Vol. 3, No. 4, 2013, pp. 54-57.

42. Koyana, DS., Bekker, JC., The Indomitable Ukuthwala Custom, De Jure, Vol. 40, No. 1, 2007, pp. 139-144.

43. Kuenyehia, A., Women, Marriage, and Intestate Succession in the Context of Legal Pluralism in Africa, University of California Davis Law Review, Vol. 40, No. 2, 2006, pp. 385-405.

44. Lee-Rife, S., Malhotra, A., Warner, A., Glinski, AM., What Works to Prevent Child Marriage: a Review of the Evidence, Studies in Family Planning, Vol. 43, No. 4, 2012, pp. 287-303.

45. Leshan, EJ., The Conspiracy Against Childhood, MacMillan Publishing Company California, 1968.

46. Linton, R., Age and Sex Categories, American Sociological Review, Vol. 7, No. 5, 1942, pp. 589-603.

47. Lowe, N., Douglas, G., Bromley's Family Law, Oxford University Press, Oxford, 2015.

48. Luker, K., Dubious Conception: The Politics of Teenage Pregnancy, Harvard University Press, Cambridge, 1996.

49. MacKinnon, CA., Sex Equality Under the Constitution of India: Problems, Prospects, and Personal Laws, International Journal of Constitutional Law, Vol. 4, No. 2, 2006, pp. 181-202.

50. Macleod, C., Teenage Pregnancy and the Construction of Adolescence: Scientific Literature in South Africa, Childhood, Vol. 10, No. 4, 2003, pp. 419-437.

51. Maluleke, TS., Nadar, S., Breaking the Covenant of Violence against Women, Journal of theology for Southern Africa, Vol. 114, 2002, pp. 5-17.

52. Maru, V., Between Law and Society: Paralegals and the Provision of Justice Services in Sierra Leone and Worldwide, Yale Journal of International Law, Vol. 31, No. 2, 2006, pp. 476 - 427.

53. Merry, SE., Legal Pluralism, Law and Society Review, Vol. 22, No. 5, 1988, pp. 869 -896.

54. Mfono, Z., The Custom of Bride Abduction Holds its own Against Time, Agenda Vol. 16, No. 45, 2000, pp. 76-80.

55. Mikhail, SL., Child Marriage and Child Prostitution: Two Forms of Sexual Exploitation, Gender and Development, Vol. 10, No. 1, 2002, pp. 43 - 49.

56. Mill, JS., On Liberty, John W. Parker and Son, West Strand, United Kingdom, 1869.

57. Mwambene, L., Sloth-Nielsen, J., Benign Accommodation? Ukuthwala, 'forced marriage' and the South African Children's Act, African Human Rights Law Journal, Vol. 11, No. 1, 2011, pp. 1-22.

58. Ncube, W., Law, Culture, Tradition and Children's Rights in Eastern and Southern Africa, Ashgate Publishing Ltd, Dartmouth, 1998.

59. Ndulo, M., African Customary Law, Customs, and Women's Rights, Indiana Journal of Global Legal Studies, Vol. 18, No. 1, 2011, pp. 87-120.

60. Nkosi, M., Wassermann, J., A History of the Practice of Ukuthwala in the Natal/KwaZulu-Natal Region up to 1994, New Contree Vol. 70, 2014, pp. 131-146.

61. Nkoyo, T., Revising Equality as a Right: The Minimum Age of Marriage Clause in the Nigerian Child Rights 2003, Third World Quarterly Vol. 27, No. 7, 2006, pp. 1299- 1312.

62. Nour, NM., Health Consequences of Child Marriage in Africa, Perspective, Vol. 12, No. 11, 2006, pp. 1644-1649. 
63. O'Connell, H., Women and the Family, Zed books, London, 1994.

64. Otoo-Oyortey, N., Pobi, S., Early Marriage and Poverty: Exploring Links for Policy and Programme Development, Gender and Development, Vol. 11, No. 2, 2003, pp. 45-51.

65. Ouattara, M., Sen, P., Thomson, M., Forced Marriage, Forced sex: The Perils of Childhood for Girls, Gender and Development, Vol. 6, No. 3, 1998, pp. 27-33.

66. Piaget, J., The Language and Thought of the Child, Psychology Press, London, 1959, 3rd ed.

67. Raj, A., When the Mother is a Child: the Impact of Child Marriage on the Health and Human Rights of Girls, Archives of Disease in Childhood, Vol. 95, No. 11, 2010, pp. 931-935.

68. Rembe, S., Chabaya, O., Wadesango, N., and Muhuro, P., Child and Forced Marriage as Violation of Women's Rights, and Responses by Member States in Southern African Development Community, Agenda Vol. 87, No. 25/1, pp. 65-74.

69. Rice, K., Ukuthwala in Rural South Africa: Abduction Marriage as a Site of Negotiation about Gender, Rights and Generational Authority among the Xhosa, Journal of Southern African Studies, Vol. 40, No. 2, 2014, pp. 381-399.

70. Richter, L., Dawes, A., C Higson-Smith., Sexual Abuse of Young Children in Southern Africa, HSRC Press, Cape Town, 2004.

71. Rutter, M., Parent-Child Separation: Psychological Effects on the Children, Journal of Child Psychology and Psychiatry, Vol. 12, No. 4, 1971, pp. 233-260.

72. Rwezaura, B., Competing Images of Childhood in the Social and Legal Systems of Contemporary Sub-Saharan Africa, International Journal of Law, Policy and Family, Vol. 12, No. 3, pp. 253- 278.

73. Saranga, J., Kurz, K., New Insights on Preventing Child Marriage: A Global Analysis of Factors and Programs, 2007.

74. Schapiro, T., What Is a Child? Ethics, Vol. 109, No. 4, 1999, pp. 715-738.

75. Scheper-Hughes, N., Child Survival:Anthropological Perspectives on the Treatment and Maltreatment of Children, Springer Science \& Business Media, Dordrecht, Boston, 1987.

76. Schwab, P., Pollis, A., Toward a Human Rights Framework, Praeger Pub Text, Westport, Connecticut, 1982.

77. Singh, K., and Kapur, D., Law, Violence, and the Girl Child, Health and Human Rights Vol. 5, No. 2, 2001, pp. 8-29.

78. Singh, S., \& Samara, R., Early Marriage among Women in Developing Countries, International Family Planning Perspectives, Vol. 22, No. 4, 1996, pp. 148-175.

79. Sohoni, N., The Burden of Girlhood: A Global Inquiry into the Status of Girls, Third Party Publishing Company, California, 1995.

80. Stephens, S., Children and the Politics of Culture, Princeton University Press, Princeton, 1995.

81. Wadesango, N., Rembe, S and Chabaya, O., Violation of Women's Rights by Harmful Traditional Practices, Anthropologist, Vol. 13, No 2, 2011, pp. 121-129.

82. Walker, JA., Early Marriage in Africa-trends, Harmful Effects and Interventions, African Journal of Reproductive Health, Vol. 16, No. 2, 2012, pp. 231-240.

83. Wanda, BP., Customary family law in Malawi: Adherence to tradition and adaptability to change, The Journal of Legal Pluralism and Unofficial Law, Vol. 20, No. 27, 1988, pp. 117-134.

84. Warner, E., Behind the Wedding Veil: Child Marriage as a Form of Trafficking in Girls, American University Journal of Gender, Social Policy and the Law, Vol. 12, No. 2, 2004, pp. 233 - 272.

85. Wolpe, H., Capitalism and cheap labour-power in South Africa: From segregation to apartheid, Economy and society, Vol. 1, No. 4, 1972, pp. 425-456. 
86. Zabin, LS., Kiragu, K., The Health Consequences of Adolescent Sexual and Fertility Behavior in Sub-Saharan Africa, Studies in Family Planning, Vol. 29, No. 2, 1998, pp. 210-232.

\section{LIST OF REGULATIONS, ACTS AND COURT DECISIONS}

1. African Charter on the Rights and Welfare of the Child, OAU Doc. CAB/LEG/24.9/49 (1990).

2. Ashworth, G., Of Violence and Violation: Women and Human Rights, 1986, Change International Reports

3. Constitution of Zimbabwe Amendment (Act No. 20) Act 2013.

4. Institutional Reform and Capacity Building Project Evaluations Unit, 'Report on the IRCBP 2007 National Public Services Survey: Public Services, Governance, Dispute Resolution and Social Dynamics' (2008).

5. International Covenant on Civil and Political Rights (ICCPR), adopted on 16 December 1966, and entered into force from 23 March 1976.

6. International Covenant on Economic, Social and Cultural Rights (ICESCR) adopted on 16 December 1966 and entered into force from 3 January 1976.

7. Marriage Act 25 of 1961

8. Plan, 'Before their time: Challenges to Implementing the Prohibition against Child Marriage in Sierra Leone' (2013).

9. SADC Protocol on Gender and Development, 2008.

10. South African Constitution 1996; Sec 266 Constitution of Zambia (Amendment) Act 2016.

11. The Children's Act of 2005 (Act No. 38 of 2005).

12. The UN Convention on the Elimination of all forms of Discrimination against Women (CEDAW) adopted in 1979 and came into force on 3 September 1981.

13. UNICEF, Early Marriage a Harmful Traditional Practice: A statistical exploration (2005).

14. United Nations General Assembly Resolution 2018 XX.

\section{WEBSITE REFERENCES}

1. Business Case: Stamping out and Preventing Gender-Based Violence and Child Marriage available online at < iati.dfid.gov.uk/iati documents/4317633.doc> Accessed on the 19 July 2015.

2. Ending child marriage in Africa A brief by Girls Not Brides http://www.girlsnotbrides.org/wp-content/uploads/2015/02/Child-marriage-in-Africa-A-brief-by-Girls-Not-Brides.pdf. Accessed on 22 June 2015.

3. Human Rights Watch, Malawi: New Marriage Law Can Change Lives, https://www.hrw.org/ news/2015/04/17/malawi-new-marriage-law-can-change-lives. Accessed 30 September 2017.

4. Makoni, C., The Constitutional Court Ruling on ending Child Marriages: An Important First Step. https://www.unicef.org/zimbabwe/media_17754.html. Accessed 7 October 2017.

5. Masina, L., Malawi Outlaws Child Marriage 2017. https://www.voanews.com/a/malawi-outlaws-child-marriage/3824898.html. Accessed 7 October 2017. 
6. Newsday Newspaper, Bill to align marriage laws with Constitution, 2017. https://www.newsday.co. zw/2017/03/bill-align-marriage-laws-constitution/. Accessed 7 October 2017.

7. SADC Parliamentary Forum, https://www.girlsnotbrides.org/wp-content/uploads/2016/10/MODEL-LAW-ON-ERADICATING-CHILD-MARRIAGE-AND-PROTECTING-CHILDREN-ALREADY-INMARRIAGE.pdf. Accessed 30 September 2017.

8. UN Women, Malawi Chief annuls 330 child marriages, 2015, http://www.unwomen.org/en/news/ stories/2015/9/malawi-chief-annuls-330-child-marriages. Accessed 14 October 2017.

9. UNICEF, The Constitutional Court Ruling on ending Child Marriages: An Important First Step, https:// www.unicef.org/zimbabwe/media_17754.html. _Accessed 28 September 2017.

\section{DISSERTATIONS}

1. Bunting, A., Particularity of rights, Diversity of contexts: Women, International Human Rights and the case of early marriage, 1999, PhD diss., National Library of Canada.

2. Iyanuolu, AE., The challenges of culture for the rights of women in Africa: A critical analysis of the protocol to the African charter on human and people's rights on the rights of women in Africa, 2008, LLM thesis UCT.

3. Jonas, B., Towards Effective Implementation of Children's Rights in Tanzania: Lessons and opportunities from Ghana and South Africa, Master's thesis, Pretoria, 2006.

4. Kanyangu, RM., Factors contribute to early marriage among teenagers in rural areas in Kasulu District Council (LLM Diss. Submitted to The Open University of Tanzania, 2014). 
Jane Diala*

\section{DIJETE U DJETETU: DJEČJI BRAK I IZGUBLJENI IDENTITET U JUŽNOJ AFRICI**}

\section{Sažetak}

U većini zajednica u subsaharskoj Africi definicije djeteta neodređene su i razlikuju se kulturološki, politički i društveno. Definicije djeteta koje nalazimo u zakonima primjerice kada se radi o problemu dječjih brakova ukazuje na različita značenja. Dječji brak koji predstavlja kršenje ljudskih prava je pravna ili običajna zajednica u kojoj su jedan ili oba supružnika mlađi od 18 godina. Ova praksa prevladava u većini zajednica u subsaharskoj Africi. Nedvojbeno takav brak uskraćuje djeci priliku da uživaju u djetinjstvu i osjećaju brižnosti, zaštite i skrbi. Umjesto toga, dječji brak ih pretvara u zaštitnike, hranitelje i skrbnike. Ona su gurnuta u odgovornu ulogu roditelja. Na taj način nestaje granica između uloge i odgovornosti odrasle osobe i djeteta. S obzirom na to da djeca nisu pripremljena za brak i sve ono što brak sa sobom donosi kao što su spolna, psihološka, emocionalna i fizička zrelost da budu supružnici i eventualno roditelji, u ovom se radu ističe da put do samospoznaje i identiteta vodi preko raskrižja kulture, zakona i religije. Sukob između vjerske i kulturne autonomije kao glavni problem u primjeni nacionalnog i međunarodnog prava proizlazi iz zahtjeva za neprimjenom propisa za zaštitu djeteta i braka u slučajevima kulturne ili vjerske autonomije. Na temelju podataka prikupljenih tijekom terenskog rada u zemljama južne Afrike i literature o kulturnom relativizmu, ovaj rad upućuje da se sukob između kulturne autonomije i zabrane dječjeg braka najbolje rješava sa stajališta pravnog pluralizma. Ovo stajalište nastoji premostiti jaz između običajnog prava, nacionalnog prava i međunarodnih ugovora te zahtijeva osjetljivost za ekonomske i sociokulturne čimbenike koji su podloga ustrajnosti na sklapanju dječjeg braka.

Ključne riječi: identitet, samospoznaja, dječji brak, ljudska prava, dob za sklapanje braka

\section{(c) (1) ( $)$}

This work is licensed under a Creative Commons

Attribution-NonCommercial 4.0 International License.

* Jane Diala, magistar pravnih znanosti, doktorand na Sveučilištu Cape Town, znanstveni suradnik u Centru za pravo i društvo Sveučilišta u Cape Townu, Private Bag X3, Rondebosch, 7701 Južna Afrika. Adresa e-pošte: jane.diala@alumni.uct.ac.za. ORCID: https://orcid.org/0000-0002-1413-0725.

** Poticaj za pisanje ovoga članka bio je projekt Centra za pravo i društvo (CLS) pod naslovom Dječji brakovi kojeg financira zaklada Ford Foundation. Ovime izražavam zahvalu glavnom istraživaču na projektu dr. Kelley Moultu. Međutim, mišljenja izražena u ovom članku ne odražavaju nužno stajališta CLS-a niti stajališta zaklade Ford Foundation. 